Acta vet. scand. $1961,2,151-156$.

From the Department of Pharmacology and Toxicology, The Royal Veterinary and Agricultural College, Copenhagen.

\title{
MAMMARY EXCRETION OF ANTIPYRINE, ETHANOL, AND UREA ${ }^{1}$ )
}

\author{
By \\ Folke Rasmussen
}

While differences in hydrogen ion concentration between milk and plasma cause drugs occurring in ionised as well as nonionised condition in biological fluids to be unevenly distributed across the lactating mammary gland membrane (Rasmussen 1958, 1959), such non-ionised substances as antipyrine, ethanol, and urea are supposed to be found in the same concentration in the two media.

Previous excretion studies have shown all three substances to be present in milk (vide Kolda 1926; Sapeika 1947; Hänni 1949; Espe \& Smith 1958). For ethanol (Olow 1923) and urea (Owen, Smith \& Wright 1943), their concentrations in milk have been stated to be of the same order as in plasma. Below, an account will be given of the mammary excretion in goats and cows at constant or slightly rising plasma levels.

\section{EXPERIMENTAL}

The experiments were carried out on cows and goats whose lactating mammary glands were found on clinical examination to be normal. The variations in urea concentration in plasma were obtained by more or less intense feeding with high-protein foodstuffs. Ethanol and antipyrine in aqueous solution were infused continuously into the left jugular vein through a plastic catheter (Roberts \& Dye 1951). Samplings were stated at least 30 minutes after the beginning of the constant infusion. Blood and milk samples were drawn six times at 30 -minute intervals.

1) Supported by a grant from Statens alm. Videnskabsfond. 
At each milking the gland was stripped completely, and the milk sample was drawn about 5 minutes later than the corresponding blood sample.

The $\mathrm{pH}$ values of the blood and milk samples were measured potentiometrically with glass electrode immediately after the sampling. The content of antipyrine was determined by the precipitation method described by Brodie, Axelrod, Soberman \& Levy (1949), while the ethanol analyses were carried out according to Widmark (1922), and urea was determined according to Conway (1950). The protein binding in blood plasma and milk was examined by ultrafiltration through cellophane membrane, as described by Poulsen (1956).

\section{RESULTS}

After concentration equilibrium had been obtained, 116 observations were made on antipyrine, 108 on ethanol, and 214 on urea on parallel plasma and milk samples. Ultrafiltration of plasma and milk through cellophane membrane showed no protein binding in the cases of ethanol and urea, and for antipyrine only at plasma and milk concentrations exceeding $20 \mu \mathrm{g} / \mathrm{ml}$., and then maximally $20 \%$ in plasma and $10 \%$ in milk. Results of experimental series with low and high plasma levels are rendered in Table 1, where mean values are given of the six single obser-

T a b l e 1.

Concentrations of antipyrine, ethanol, and urea in plasma- and milk water.

\begin{tabular}{lccccc}
\hline & $\mathrm{pK}_{\mathrm{a}}$ & $\begin{array}{c}\text { Non-ionised } \\
\text { in plasma } \\
\text { and milk } \\
\text { \% }\end{array}$ & $\begin{array}{c}\text { Plasma } \\
\mu \mathrm{g} / \mathrm{ml} .\end{array}$ & $\begin{array}{c}\text { Milk } \\
\mu \mathrm{g} / \mathrm{ml} .\end{array}$ & $\begin{array}{c}\text { Ratio } \\
\mathrm{M} / \mathrm{P}\end{array}$ \\
\hline Antipyrine & 1.4 & 100 & 13.7 & 13.9 & 1.02 \\
Ethanol & & 100 & 750 & 730 & 0.97 \\
Urea & & & 2020 & 1880 & 0.93 \\
& 0.2 & 100 & 130.1 & 125.3 & 0.96 \\
& & & 521.8 & 510.6 & 0.98 \\
\hline
\end{tabular}

1) Corrected for protein binding.

vations in each experiment. The milk/plasma $(M / P)$ ratios were in all cases about 1.

When spontaneous $\mathrm{pH}$ alterations in the milk during the 


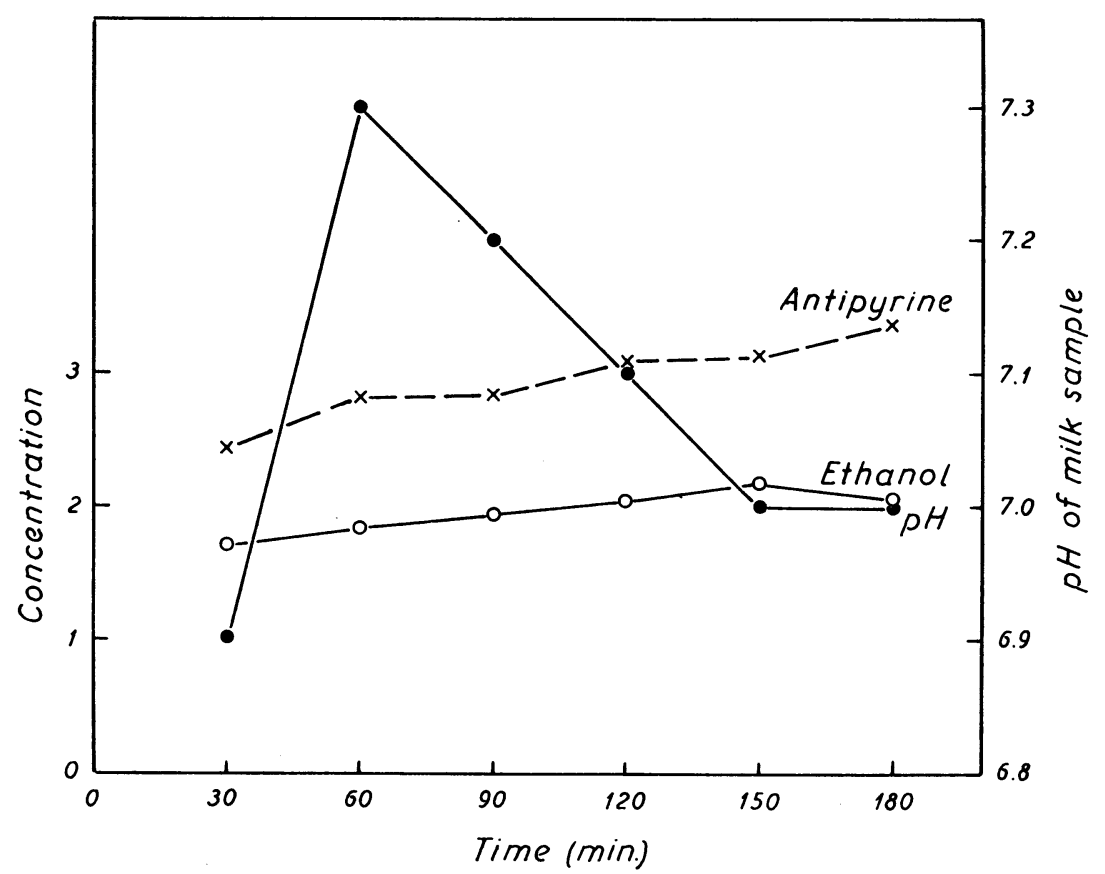

F i g. 1. Concentrations of antipyrine and ethanol in milk at different $\mathrm{pH}$ values.

Ordinate: To the left the concentration of antipyrine in $100 \mu \mathrm{g} / \mathrm{ml}$. and of ethanol in $1000 \mu \mathrm{g} / \mathrm{ml}$., to the right the $\mathrm{pH}$ of the milk.

Abscissa: Time in minutes.

experiments were observed this condition was never accompanied by abrupt changes in the milk concentrations of antipyrine, ethanol, and urea. This is seen in Fig. 1, which shows very considerable variations in the $\mathrm{pH}$ of the milk, while at the same time the concentrations of antipyrine and ethanol rose steadily, similarly as those in plasma. The latter rose within the experimental period from 220 to $290 \mu \mathrm{g} / \mathrm{ml}$. for antipyrine and from 1780 to $2140 \mu \mathrm{g} / \mathrm{ml}$. for ethanol.

By the modification described below of the experimental technique it was, further, shown that the concentrations of the three test substances in the milk were independent of the quantity of milk produced. At the start of the experiments on goats one udder half and on cows two quarters were not milked, whereas the other (-s) were stripped completely. This gave considerable differences in milk volume at the samplings about 1 hour after the continuous intravenous infusion had been started 
when the glands were stripped completely. The milk volume was measured, and the concentrations of antipyrine, ethanol, and urea respectively were determined. In Table 2 are recorded the

Table 2 .

Independence of the quantity of milk on the concentration in milk.

\begin{tabular}{|c|c|c|c|c|c|}
\hline & & \multicolumn{2}{|c|}{$\begin{array}{l}\text { Mammary gland } \\
\text { volume of milk }\end{array}$} & \multicolumn{2}{|c|}{$\begin{array}{c}\text { Mammary gland } \\
\text { concentration in milk }\end{array}$} \\
\hline & & $\begin{array}{l}\text { full } \\
\text { ml. }\end{array}$ & $\begin{array}{c}\text { empty } \\
\text { ml. }\end{array}$ & $\begin{array}{l}\text { full } \\
\mu \mathrm{g} . / \mathrm{ml} .\end{array}$ & $\begin{array}{l}\text { empty } \\
\mu \mathrm{g} . / \mathrm{ml} \text {. }\end{array}$ \\
\hline \multirow[t]{2}{*}{ Antipyrine } & Cow & 350 & 13 & 96 & 99 \\
\hline & Cow & 1400 & 16 & 70 & 66 \\
\hline \multirow[t]{2}{*}{ Ethanol } & Cow & 900 & 11 & 1060 & 1060 \\
\hline & Cow & 900 & 21 & 690 & 720 \\
\hline \multirow[t]{2}{*}{ Urea } & Goat & 350 & 13 & 294 & 285 \\
\hline & Goat & 600 & 10 & 492 & 486 \\
\hline
\end{tabular}

volumes of milk from the glands not stripped before the start of the experiment (full) as well as the milk volume from the stripped glands (empty). Further, the concentrations are given of antipyrine, ethanol, and urea in the milk from the glands concerned. In spite of the very great difference in milk volume the concentrations of the test compound were always the same in the milk from the two glands.

\section{DISCUSSION}

The fact that the concentrations of antipyrine, ethanol, and urea in milk from cows and goats at constant or slightly rising plasma levels are equal to those in simultaneously drawn plasma samples and independent of the quantity of milk produced bears out the hypothesis that the mammary excretion of these substances occurs by diffusion. Thus, the membrane between plasma and milk behaves, with regard to permeability, exactly like other membranes across which the passage of the test substances employed have been investigated.

Rall, Stabenau \& Zubrod (1959) have shown that the cerebrospinal fluid/plasma ratio for antipyrine is 1 , and that antipyrine diffuses rapidly across the so-called blood-liquor barrier. Coldwell \& Smith (1959) found the concentrations of ethanol in saliva and urine to be directly proportional to that in the blood. The ratios were 1.12 and 1.24 respectively. 
According to several papers reviewed by Davson (1956), the concentrations of urea in aqueous humour and cerebrospinal fluid are directly proportional to, but lower than that in plasma. Regarding the distribution of urea across various other membranes, Thaysen \& Thorn (1954) state, however, that the concentration in lacrimal fluid is identical with that in plasma. The urea concentration in sweat, on the other hand, is, according to Schwartz, Thaysen \& Dole (1953), higher than that in plasma due to reabsorption of water but the ratio (1.84) is constant, independent of the intensity of secretion and the plasma level. In these two latter works the facts are established that the excretion of urea occurs by diffusion, and that there is no difference in principle between the permeability of these glandular epithelia and that of the other membranes of the organism.

The view advanced that the urea content in milk never exceeds $280 \mu \mathrm{g} / \mathrm{ml}$ (Espe \& Smith 1958) has not been borne out in the present investigation, the concentration in milk having here always been equal to that in plasma within a concentration range of $100-700 \mu \mathrm{g} / \mathrm{ml}$. The constant $\mathrm{M} / \mathrm{P}$ ratio of 1 observed in the present investigations also militates against Graham, Houchin \& Turner's observation (1937) that urea is produced in the mammary tissue. Their observation was neither confirmed by Bouckaert, Oyaert, Peeters \& Sierens (1953) in their work with perfusion of isolated mammary glands.

\section{REFERENCES}

Bouckaert, J. H., W. Oyaert, G. Peeters \& G. Sierens: Arch. int. Pharmacodyn, 1953, 93, 443.

Brodie, B. B., J. Axelrod, R. Soberman \& B. B. Levy: J. biol. Chem. $1949,179,25$.

Coldwell, B. B. \& H. Ward Smith: Can. J. Biochem. Physiol. 1959, 37, 43.

Conway, E. J.: Microdiffusion Analysis and Volumetric Error, London 1950, p. 152.

Davson, H.: Physiology of the Occular and Cerebrospinal Fluids, London 1956, p. 284.

Espe, Dwight \& Vearl R. Smith: Secretion of Milk, Ames, Iowa 1952, p. 215.

Graham, W. R., O. B. Houchin \& C. W. Turner: J. biol. Chem. 1937, $120,29$.

Hänni, H.: Mitteilung. aus dem Gebiete d. Lebensm. untersuch. u. Hygien. 1949, 40, 119.

Kolda, J.: Le Lait 1926, 6, 180.

Olow, J.: Biochem. Z. 1923, 134, 553. 
Owen, E. C., J. A. B. Smith \& N. C. Wright: Biochem. J. 1943, 37, 44.

Poulsen, E.: Renale Clearanceunders $\varnothing$ gelser hos Køer, København 1956, p. 42.

Rall, D. P., J. R. Stabenau \& C. G. Zubrod: J. Pharmacol. 1959, 125, 185.

Rasmussen, Folke: Acta pharmacol. toxicol. 1958, 15, 139.

Rasmussen, Folke: Acta pharmacol. toxicol. 1959, 16, 194.

Roberts, S. J. \& J. A. Dye: Cornell Vet. 1951, 41, 3.

Sapeika, N.: J. Obst. Gynaecol. 1947, 54, 426.

Schwartz, I. L., J. H. Thaysen \& V. P. Dole: J. exper. Med. 1953, 97, 429.

Thaysen, J. H. \& N. A. Thorn: Amer. J. Physiol. 1954, 178, 160.

Widmark, E. M. P.: Biochem. Z. 1922, 131, 473.

\section{SUMMARY}

It has been shown in experiments on goats and cows with constant or slightly rising plasma levels of antipyrine, ethanol, and urea, all substances non-ionised in biological media, that the concentration in milk is equal to that in plasma. The $M / P$ ratio for the three compounds is 1 , independent of the quantity of milk produced and changes in the $\mathrm{pH}$ of the milk.

\section{ZUSAMMENFASSUNG}

Mammäre Exkretion von Antipyrin, Aethanol und Harnstoff.

In Versuchen an Ziegen und Kühen mit einer im Plasma konstanten oder schwach steigenden Konzentration der in biologischen Medien nichtionisierten Stoffe Antipyrin, Aethanol und Harnstoff hat es sich gezeigt, dass die Konzentration in der Milch identisch mit der Konzentration im Plasma ist. Das Verhältnis von Milch zu Plasma beträgt für alle drei Stoffe 1, und ist unabhängig von der produzierten Milchmenge und den Änderungen im pH-Wert der Milch.

\section{RESUME}

Mammær ekskretion af antipyrin, ætanol og urinstof.

I fors $\emptyset$ g på geder og køer med en konstant eller svagt stigende koncentration i plasma af de i biologiske medier ikke ioniserede stoffer antipyrin, ætanol og urinstof er det vist, at koncentrationen i mælk er identisk med koncentrationen i plasma. Ratio mælk/plasma er for alle tre stoffer 1, uafhængig af den producerede mælkemængde og ændringer i mælkens pH. 